\title{
Pharmacological Profiles of Muscarinic Receptors in the Longitudinal Smooth Muscle of Guinea Pig Ileum
}

\author{
Kenji Honda, Yukio Takano and Hiro-o Kamiya \\ Department of Pharmacology, Faculty of Pharmaceutical Sciences, Fukuoka University, Fukuoka 814-01, Japan
}

Received August 25, 1992 Accepted Jamuary 26, 1993

\begin{abstract}
We have examined the pharmacological subtypes of muscarinic receptors mediating phosphoinositide hydrolysis and contraction in the longitudinal smooth muscle of guinea pig ileum with the use of muscarinic antagonists. Carbachol increased the formation of ${ }^{3} \mathrm{H}$-inositol phosphates (IPs) in a dosedependent manner in both ileal smooth muscle and the frontal cortex of rats. The rank order of muscarinic antagonists for inhibition of IP formation induced by carbachol was 4-DAMP $=$ atropine $>$ pirenzepine $>$ AF-DX 116 in guinea pig ileal smooth muscle. In ileal smooth muscle, the inhibition by the $M_{1}$ antagonist pirenzepine was about 15 times less than that by atropine. However, in the rat frontal cortex, the inhibition by pirenzepine was only about 3 times less than that by atropine. The inhibitory effect of the $\mathrm{M}_{2}$ antagonist AF-DX 116 was weak in both ileal muscle and the frontal cortex. The $\mathrm{M}_{3}$ antagonist 4-DAMP strongly inhibited carbachol-induced IP formation in ileal smooth muscle. The rank order of muscarinic antagonists for inhibition of contraction induced by $10^{-7} \mathrm{M}$ carbachol was atropine $\geqq 4$-DAMP $>$ pirenzepine $>$ AFDX 116. These results suggest that both IP formation and the contractile response induced by muscarinic agonists are mediated through the muscarinic $\mathbf{M}_{3}$ subtype in guinea pig ileum.
\end{abstract}

Keywords: Ileum (guinea pig), Muscarinic antagonist, Phosphoinositide response, Muscarinic $\mathrm{M}_{3}$ subtype

Functional and ligand binding studies have provided evidence for the existence of multiple subtypes of muscarinic receptors in central and peripheral tissues $(1,2)$. Recently, these muscarinic receptors have been classified into $M_{1}, M_{2}$ and $M_{3}$ subtypes based on the effects of the selective antagonists pirenzepine $\left(\mathrm{M}_{1}\right)$, AF-DX 116 (11[[2-[(diethylamino)methyl]-1-piperidinyl]acetyl]-5,11-dihydro-6 $H$-pyrido[2,3-b][1,4]benzodiazepine-6-one) $\left(\mathrm{M}_{2}\right)$ and 4-DAMP (4-diphenylacetoxy- $N$-methylpiperidine methiodide) $\left(M_{3}\right)(3-7)$. Furthermore, molecular cloning studies have demonstrated that $\mathbf{M}_{1}, \mathbf{M}_{2}$ and $\mathbf{M}_{3}$ closely resemble the $m 1, m 2$ and $m 3$ gene products $(8,9)$. Each subtype of the muscarinic receptor is coupled to a second messenger system $(10,11)$. The $\mathrm{m} 1, \mathrm{~m} 3$ and $\mathrm{m} 5$ subtypes have been reported to be coupled to stimulation of phosphoinositide (PI) hydrolysis (12-14), and the $\mathrm{m} 2$ and $\mathrm{m} 4$ subtypes to inhibition of adenylate cyclase $(12,14)$.

In ileal smooth muscle, radioligand binding studies and Northern blot analysis of mRNA of acetylcholine receptors have indicated the presence of a large population of $\mathrm{M}_{2}$ subtypes, but only a small population of $\mathbf{M}_{3}$ subtypes $(15,16)$. The presence of $m 4$ receptors in ileal smooth muscle has also been shown by using muscarinic receptorspecific antiserum (17). These findings indicate that the population of muscarinic receptors is heterogeneous in ileal smooth muscle. In addition, pharmacological studies suggest that the muscarinic agonist carbachol stimulates $P I$ hydrolysis through the non- $\mathrm{M}_{1}$ and non- $\mathrm{M}_{2}$ subtype in guinea pig ileum (18) and that the carbachol-induced contraction is caused by the $M_{3}$ subtype (19).

In this work, we made a more refined characterization of the muscarinic subtypes mediating PI hydrolysis in the longitudinal smooth muscle of guinea pig ileum. In addition, we compared the results on PI hydrolysis in smooth muscle with those in the frontal cortex of rats.

\section{MATERIALS AND METHODS}

Animals

Male Hartley guinea pigs $(300-400 \mathrm{~g})$ and male Wistar rats $(250-300 \mathrm{~g}$ ) from Kyudo (Kumamoto) were housed in a room at $20-25^{\circ} \mathrm{C}$ with a 12 -hr light-dark cycle (light on 7:00 AM) and were given free access to commercial food and tap water. 


\section{Tissue preparation}

Guinea pigs were decapitated, and the small intestine was promptly removed and placed in oxygenated KrebsRinger bicarbonate buffer solution (KRB) of the following composition: $123 \mathrm{mM} \mathrm{NaCl}, 5.0 \mathrm{mM} \mathrm{KCl}, 1.3 \mathrm{mM}$ $\mathrm{MgCl}_{2}, 1.4 \mathrm{mM} \mathrm{K \textrm {KH } _ { 2 } \mathrm { PO } _ { 4 } , 2 6 . 0 \mathrm { mM } \mathrm { NaHCO }}, 0.8 \mathrm{mM}$ $\mathrm{CaCl}_{2}$ and $1.0 \mathrm{mM}$ glucose. The longitudinal muscle layer was then isolated.

Rats were killed by decapitation, and their brains were rapidly removed. Thin sections (400- $\mu$ m thickness) were cut with a McIlwain tissue chopper in a cold room. Samples of the frontal cortex were obtained with a micropuncture technique (20).

\section{Formation of ${ }^{3} \mathrm{H}$-inositol phosphates (IPs)}

Experiments on ${ }^{3} \mathrm{H}$-IP formation were performed as described previously (21). The longitudinal muscle layer was cut into 20 pieces of approximately $10-\mathrm{mm}$ length, which were preincubated for $10 \mathrm{~min}$ in KRB at $37^{\circ} \mathrm{C}$ under $5 \% \mathrm{CO}_{2}-95 \% \mathrm{O}_{2}$ and then prelabelled with $30 \mu \mathrm{Ci}$ of Dmyo- ${ }^{3} \mathrm{H}$-inositol in $5 \mathrm{ml}$ of $\mathrm{KRB}$ for $3 \mathrm{hr}$ at $37^{\circ} \mathrm{C}$. The labelled strips were washed with KRB to remove excess Dmyo- ${ }^{3} \mathrm{H}$-inositol and then weighed. The frontal cortex of rats was also prelabelled with $3 \mu \mathrm{Ci}$ of $\mathrm{D}-\mathrm{myo}-{ }^{3} \mathrm{H}$-inositol at $37^{\circ} \mathrm{C}$ for $90 \mathrm{~min}$.

Prelabelled longitudinal muscle and rat frontal cortex were preincubated for $10 \mathrm{~min}$ in KRB solution in which $\mathrm{NaCl}$ was replaced by $10 \mathrm{mM} \mathrm{LiCl}$. Muscarinic agonists were added to the $\mathrm{KRB}$ solution containing $\mathrm{LiCl}$ and incubated under $5 \% \mathrm{CO}_{2}-95 \% \mathrm{O}_{2}$ at $37^{\circ} \mathrm{C}$ for $30 \mathrm{~min}$ (longitudinal muscle) or $60 \mathrm{~min}$ (frontal cortex). The muscarinic antagonists were applied before incubation with the agonists. Reactions were terminated by addition of icecold chloroform/methanol $(1: 2$ by $v / v)$. The mixtures were then homogenized in a glass homogenizer (longitudinal muscle) or with a sonicator (frontal cortex). The homogenates were mixed with equal volumes of water and chloroform and then centrifuged at $1,000 \times g$ for 10 $\mathrm{min}$. The upper aqueous phase was removed for measurement of ${ }^{3} \mathrm{H}$-IPs. ${ }^{3} \mathrm{H}$-IPs were separated by anion exchange chromatography by the method of Berridge et al. (22). ${ }^{3} \mathrm{H}-\mathrm{IP}$ s were separated on Dowex AG-X 8 resin (formate form), and aliquots were counted by liquid scintillation spectrometry (LKB: Pharmacia Biotech., Uppsala, Sweden). Values of IPs are expressed as percent increases over the basal level.

$\mathrm{ED}_{50}$ and $\mathrm{IC}_{50}$ values were determined by Hill plots. Protein in the frontal cortex was measured by the method of Lowry et al. (23).

\section{Contractile response}

The ileum was removed, and the longitudinal smooth muscle was carefully stripped off. Smooth muscle strips of 1.5-cm length were mounted in an organ bath containing $5 \mathrm{ml}$ of $\mathrm{KRB}(127 \mathrm{mM} \mathrm{NaCl}, 2.5 \mathrm{mM} \mathrm{KCl}, 1.8 \mathrm{mM}$ $\mathrm{CaCl}_{2}, 1.2 \mathrm{mM} \mathrm{MgSO}_{4}, 1.2 \mathrm{mM} \mathrm{NaH} \mathrm{PO}_{4}, 25 \mathrm{mM}$ $\mathrm{NaHCO}_{3}$ and $10.0 \mathrm{mM}$ glucose), which was gassed with a mixture of $95 \% \mathrm{O}_{2}$ and $5 \% \mathrm{CO}_{2}$. The buffer was maintained at $37{ }^{\circ} \mathrm{C}$, and a mixture of $95 \% \mathrm{O}_{2}$ and $5 \% \mathrm{CO}_{2}$ was bubbled through it continuously. The tissue was maintained under a resting tension of $1 \mathrm{~g}$. Contractile responses to drugs were recorded with a transducer (Sanei, Tokyo), and mean values were calculated as percentages of the maximum response evoked by $10^{-7} \mathrm{M}$ carbachol.

\section{Drugs}

D-myo- ${ }^{3} \mathrm{H}$-Inositol (specific activity, $703 \mathrm{GBq} / \mathrm{mmol}$ ) was obtained from Amersham (Buckinghamshire, UK). Atropine and carbachol were purchased from Merck (Darmstadt, Germany). Oxotremorine sesquifumarate was from Sigma (St. Louis, MO, USA). 4-DAMP was from Research Biochemicals (Natick, MA, USA). Pirenzepine and AF-DX 116 were gifts from Boehringer Ingelheim (Ingelheim am Rhein, Germany).

\section{RESULTS}

In a preliminary experiment, we examined the time courses of the formations of inositol monophosphate $\left(\mathrm{IP}_{1}\right)$, inositol bisphosphate $\left(\mathrm{IP}_{2}\right)$ and inositol trisphosphate $\left(\mathrm{IP}_{3}\right)$ induced by carbachol $\left(10^{-4} \mathrm{M}\right)$ in guinea pig ileal smooth muscle. Carbachol induced linear increases of ${ }^{3} \mathrm{H}$ $\mathrm{IP}_{1}, \mathrm{IP}_{2}$ and $\mathrm{IP}_{3}$ formation for $30 \mathrm{~min}$ after its addition in smooth muscle and for $60 \mathrm{~min}$ in rat frontal cortex (data not shown). In this study, PI hydrolysis was expressed as the total amount of ${ }^{3} \mathrm{H}$-IPs $\left(\mathrm{IP}_{1}, \mathrm{IP}_{2}\right.$ and $\left.\mathrm{IP}_{3}\right)$, since $\mathrm{IP}_{1}$ constituted more than $80 \%$ of the total inositol phosphates on stimulation with muscarinic agonists in both tissues.

The relative potencies of muscarinic agonists to stimulate formations of IPs in guinea pig ileal smooth muscle and rat frontal cortex were compared (Fig. 1: A, B and Table 1). Dose-dependent increase in the formation of ${ }^{3} \mathrm{H}$-IPs were observed with carbachol in both the ileal smooth muscle and the frontal cortex. However, oxotremorine was a very weak stimulator of IP formation in the rat frontal cortex (Fig. 1B).

Muscarinic antagonists dose-dependently inhibited the carbachol-induced formation of IPs. As shown in Fig. 2, the rank order of the $\mathrm{IC}_{50}$ values of muscarinic antagonists for IP formation was 4-DAMP $=$ atropine $>$ pirenzepine $>$ AF-DX 116 in the ileal smooth muscle of guinea pigs. In the ileal muscle, the inhibition by the $M_{1}$ antagonist pirenzepine was 14.8 -fold less than that by atropine, whereas, in the rat frontal cortex, the inhibition 
(A)

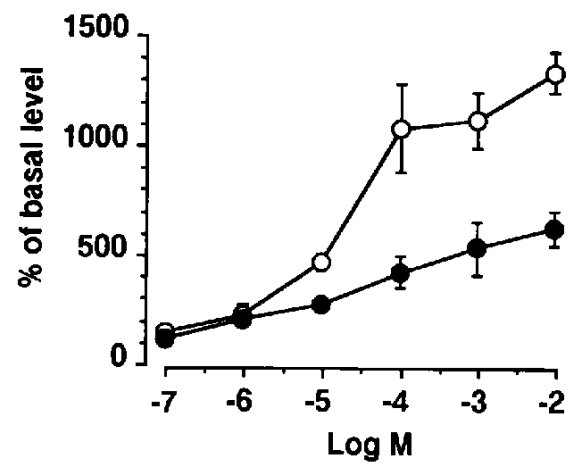

(B)

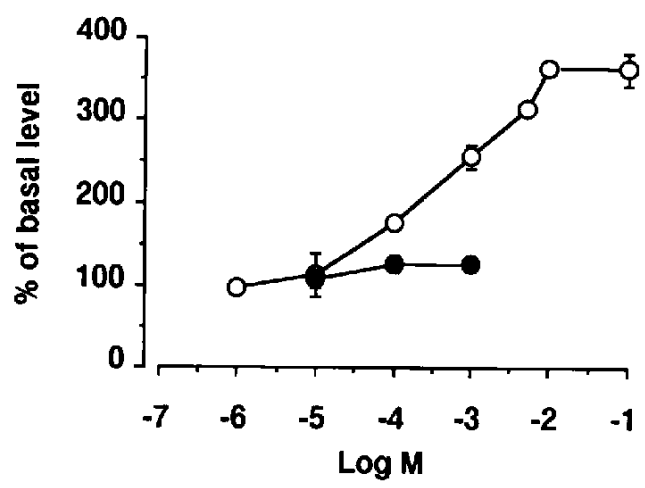

Fig. 1. Concentration-response curve for the formation of ${ }^{3} \mathrm{H}-\mathrm{IPs}$ in longitudinal smooth muscle of guinea pig ileum (A), and rat frontal cortex (B). IP formations are expressed as percentages of the basal level $(106.47 \pm 8.84 \mathrm{dpm} / \mathrm{mg}$ tissues in the ileum and 5.58 $\pm 0.57 \mathrm{dpm} / \mu \mathrm{g}$ protein in the frontal cortex, respectively). Values are means \pm S.E.M. for 3-5 experiments. $\bigcirc$ : carbachol, $\bigcirc$ : oxotremorine.

Table 1. $\mathrm{EC}_{50}$ values of muscarinic agonists on formation of ${ }^{3} \mathrm{H}$ IPs

\begin{tabular}{lcc}
\hline Agonists & $\begin{array}{c}\text { Ileal muscle } \\
\mathrm{EC}_{50}(\mathrm{M})\end{array}$ & $\begin{array}{c}\text { Frontal cortex } \\
\mathrm{EC}_{50}(\mathrm{M})\end{array}$ \\
\hline Carbachol & $2.82 \times 10^{-5}$ & $4.93 \times 10^{-4}$ \\
Oxotremorine & $3.98 \times 10^{-5}$ & $2.19 \times 10^{-5}$ \\
\hline
\end{tabular}

Mean $\mathrm{EC}_{50}$ values were calculated from $3-5$ separate determinations of the dose-response curves.

by pirenzepine was only 2.8 -fold less than that by atropine (Fig. 2 and Table 2). Thus pirenzepine was more effective in the frontal cortex $\left(\mathrm{IC}_{50}: 8.44 \times 10^{-8} \mathrm{M}\right)$ than in ileal smooth muscle $\left(\mathrm{IC}_{50}: 3.77 \times 10^{-7} \mathrm{M}\right)$. The inhibitory abilities of the $\mathrm{M}_{2}$ antagonist AF-DX 116 were weak in both the ileal smooth muscle $\left(\mathrm{IC}_{50}: 2.46 \times 10^{-6} \mathrm{M}\right)$ and frontal cortex $\left(\mathrm{IC}_{50}: 2.74 \times 10^{-6} \mathrm{M}\right)$. The $\mathrm{M}_{3}$ antagonist 4DAMP strongly inhibited carbachol-induced IP formation in ileal smooth muscle $\left(\mathrm{IC}_{50}: 1.52 \times 10^{-8} \mathrm{M}\right)$, show-

\section{(A)}

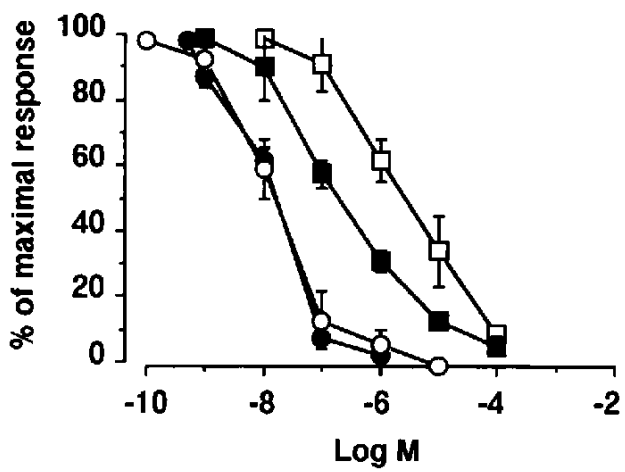

(B)

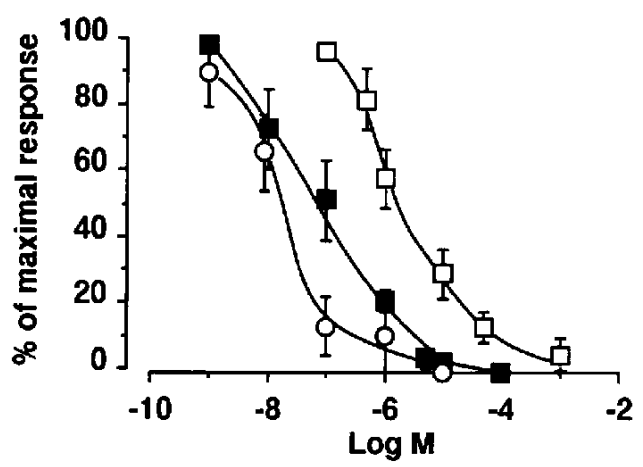

Fig. 2. Effects of muscarinic antagonists on carbachol-induced formation of ${ }^{3} \mathrm{H}$-IPs in the longitudinal smooth muscle of guinea pig ileum $\left(10^{-4} \mathrm{M}\right.$ carbachol) (A), and rat frontal cortex $\left(10^{-3} \mathrm{M}\right.$ carbachol) (B). Values are means \pm S.E.M. for 3-5 experiments. $\square$ : AF-DX 116, $\square$ : pirenzepine, : 4-DAMP, $\bigcirc$ : atropine.

Table 2. IC 50 values for muscarinic antagonists on carbachol-induced ${ }^{3} \mathrm{H}$-IP formation and contraction

\begin{tabular}{lcccc}
\hline \multirow{2}{*}{ Antagonist } & \multicolumn{2}{c}{ IP formation } & & Contraction \\
\cline { 2 - 3 } \cline { 5 - 5 } & $\begin{array}{c}\text { Ileal muscle } \\
\mathrm{IC}_{50}(\mathrm{M})\end{array}$ & $\begin{array}{c}\text { Frontal cortex } \\
\mathrm{IC}_{50}(\mathrm{M})\end{array}$ & $\begin{array}{c}\text { Ileal muscle } \\
\mathrm{IC}_{50}(\mathrm{M})\end{array}$ \\
\hline Atropine & $2.55 \times 10^{-8}$ & $4.93 \times 10^{-8}$ & & $9.33 \times 10^{-9}$ \\
4-DAMP & $1.52 \times 10^{-8}$ & - & & $3.98 \times 10^{-8}$ \\
Pirenzepine & $3.77 \times 10^{-7}$ & $8.44 \times 10^{-8}$ & & $1.17 \times 10^{-6}$ \\
AF-DX116 & $2.46 \times 10^{-6}$ & $2.74 \times 10^{-6}$ & & $3.55 \times 10^{-6}$ \\
\hline
\end{tabular}

Mean $\mathrm{IC}_{50}$ values were calculated from 3-5 separate determinations of Hill plots.

ing almost the same potency as atropine. The rank order of muscarinic antagonists for inhibition of contraction induced by $10^{-7} \mathrm{M}$ carbachol was atropine $\geqq 4$-DAMP > pirenzepine $>$ AF-DX 116. This rank order of potency was similar to that for the inhibition of IP hydrolysis (Fig. 3 and Table 2). 


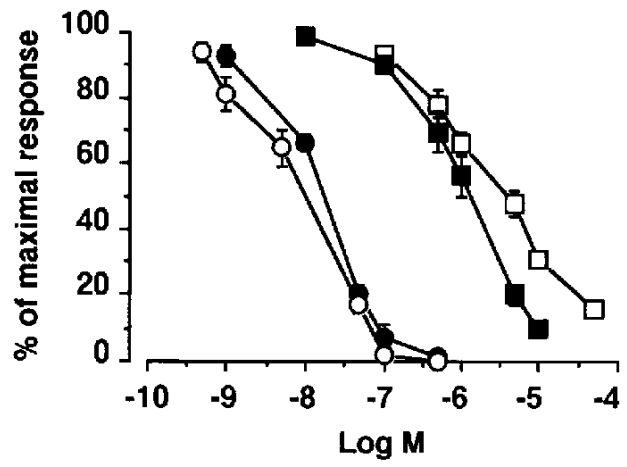

Fig. 3. Effects of muscarinic antagonists on carbachol $\left(10^{7} \mathrm{M}\right)$ induced contractions in longitudinal smooth muscle of guinea pig ileum. Values are means \pm S.E.M. for $3-5$ experiments. $\square$ : AF-DX 116, $\mathbf{0}$ : pirenzepine, $\mathrm{O}$ : $\mathrm{DAMP}, \mathrm{O}$ atropine.

\section{DISCUSSION}

In this study, we found that carbachol acts as a full agonist on the formation of IPs, whereas oxotremorine appears to be a week partial agonist in both guinea pig ileal smooth and the frontal cortex of rat. Similar findings on the effects of muscarinic agonists on IP formations have been obtained in the cerebral cortex $(10,24,25)$, astrocytoma $1321 \mathrm{~N} 1$ cells (26), chick embryo heart (27), and guinea pig bladder and colon (28).

In the present study, we used the selective muscarinic antagonists pirenzepine, AF-DX 116 and 4-DAMP to examine the subtype of muscarinic receptors that mediates IP formation. The inhibitory effect of the $\mathbf{M}_{2}$ antagonist AF-DX 116 on carbachol-induced IP formation was weak in both the smooth muscle of guinea pig ileum and the frontal cortex of rats, suggesting that involvement of the cardiac $\mathbf{M}_{2}$ subtype is negligible in these tissues. The inhibitory effects of the $\mathrm{M}_{1}$ antagonist pirenzepine on carbachol-induced IP formations were greater in the frontal cortex than in the ileal smooth muscle of guinea pigs. Pirenzepine also has weaker effects on other smooth muscles than on brain tissues (27-31). Binding studies have also indicated that pirenzepine has very high affinity to the muscarinic receptor in the cerebral cortex of rat brain $(2,32)$. These observations suggest that the $M_{1}$ subtype coupled to IP formation is predominant in the brain.

4-DAMP, which is thought to be a very selective antagonist of the $M_{3}$ subtype $(6,7)$, strongly inhibited carbachol-induced IP formation in ileal smooth muscle, being more potent than pirenzepine and AF-DX 116 (Fig. 2).

Konno and Takayanagi have found that the muscarinic receptor linked to PI turnover is associated with the smooth muscle $\mathbf{M}_{2}$ subtype by experiments using a muscar- inic antagonist, himbacine (18). It has been reported that the smooth muscle $M_{2}$ subtype $\left(M_{2 \beta}\right)$ corresponds to the $\mathbf{M}_{3}$ subtype $(7,33)$. However, the difference between the inhibitory potency of himbacine and that of the $\mathbf{M}_{1}$ antagonist pirenzepine on IP formations induced by carbachol is small. In this study, the $\mathrm{M}_{3}$ antagonist 4-DAMP strongly inhibited carbachol-induced IP formation in ileal smooth muscles, showing almost the same potency as atropine. Therefore, we can suggest that the muscarinic receptor subtype linked to PI turnover in guinea pig ileum is related to the $M_{3}$ subtype. The inhibitory effect of 4DAMP on the carbachol-induced contractile response was also the most potent (Fig. 3). These results suggest that IP formation in the ileum may be mediated through the $\mathrm{M}_{3}$ subtype, although the population of the $\mathrm{M}_{3}$ subtype is thought to be small in the tissue $(15,16,34,35)$. Further studies are needed to clarify the subtype of muscarinic receptors in the ileum using other specific agonists or antagonists, as functional $\mathrm{M}_{2}(\mathrm{~m} 2)$ and $\mathrm{m} 4$ subtypes have recently been identified in the ileum by binding and immunological studies $(15-17)$.

We conclude that IP formation and the contractile response seem to be mediated by the $\mathrm{M}_{3}$ subtype in guinea pig ileum, whereas IP formations in the rat frontal cortex are mediated by the $M_{1}$ subtype.

\section{Acknowledgments}

This work was supported in part by a Grant-in-Aid from the Ministry of Education, Science and Culture of Japan. We are grateful to Boehringer-Ingelheim (Germany) for the gifts of AF-DX 116 and pirenzepine.

\section{REFERENCES}

1 Birdsall, N.J.M., Burgen, A.S.V., Hummer, R., Hulme, E.C. and Stockon, J.: Pirenzepine - a ligand with original binding properties to muscarinic receptors. Scand. J. Gastroenterol. Supp. 15, $1-4$ (1980)

2 Hammer, R., Berrie, C.P., Birdsall, N.J.M., Burgen, A.S.V. and Hulme, E.C.: Pirenzepine distinguishes between different subtypes of muscarinic receptors. Nature 238, 90-92 (1980)

3 Hammer, R.: Subclass of muscarinic receptors and pirenzepine: further experimental evidence. Scand. J. Gastroenterol. Supp. 17, 59-67 (1982)

4 Eglen, R.M. and Whiting, R.L.: Muscarinic receptor subtypes: a critique of the current classification and a proposal for a working nomenclature. J. Auton. Pharmacol. 5, 323-346 (1986)

5 Hammer, R., Giraldo, E., Schiavi, G.B., Monferini, E. and Ladinsky, H.: Binding profile of a novel cardioselective muscarinic receptor antagonist, AF-DX 116 to membrane of peripheral tissues and brain in rat. Life Sci. 38, 1653-1662 (1986)

6 de Jonge, A., Doods, H.N., Riesbos, J. and van Zwieten, P.A.: Heterogeneity of muscarinic binding sites in rat brain, submandibular gland and atrium. Br. J. Pharmacol. 89, Supp. 551P (1986)

7 Doods, H.M., Mathy, M.J., Davidesko, D., Van Charldorp, 
K.J., de Jonge, A. and van Zwieten, P.A.: Selectivity of muscarinic antagonists in radioligand and in vivo experiments for the putative $\mathbf{M}_{1}, \mathbf{M}_{2}$ and $\mathbf{M}_{3}$ receptors. J. Pharmacol. Exp. Ther. 242, 257-262 (1987)

8 Kubo, T., Fukuda, K., Mikami, A., Maeda, A., Takahashi, H., Mishina, M., Haga, T., Haga, K., Ichiyama, A., Kangawa, K., Kojima, M., Matsuo, H., Hirose, T, and Numa, S.: Cloning, sequencing and expression of complementary DNA encoding the muscarinic acetylcholine receptor. Nature 323, 411-416 (1986)

9 Bonner, T.I.: The molecular basis of muscarinic receptor diversity. Trends Neurosci. 12, 148 (1989)

10 Brown, J.H. and Brown, L.: Agonists differentiate muscarinic receptors that inhibit cyclic AMP formation from those that stimulate phosphoinositide metabolism. J. Biol. Chem. 259, 3777-3781 (1984)

11 Nathanson, N.M.: Moleculor properties of the muscarinic acetylcholine receptor subtype. Annu. Rev. Neurosci. 10, 195-236 (1987)

12 Peralta, E.G., Ashkenazi, A., Winslow, J.W., Ramachandran, J. and Capton, D.J.: Differential regulation of PI hydrolysis and adenylyl cyclase by muscarinic receptor subtypes. Nature 334, 434-437 (1988)

13 Laio, C.F., Themmen, A.P.N., Joho, R., Barberis, C., Birnbaumer, $M$. and Birnbaumer, L.: Molecular cloning and expression of a fifth muscarinic acetylcholine receptor. J. Biol. Chem. 264, 7328-7337 (1989)

14 Lamber, D.G., Burford, N.T. and Nahorski, S.R.: Muscarinic receptor subtypes: inositol phosphates and intracellular calcium. Biochem. Soc. Trans. 20, 130-135 (1992)

15 Maeda, A., Kubo, T., Mishina, M. and Numa, S.: Tissue distribution of mRNAs encoding muscarinic acetylcholine receptor subtypes. FEBS Lett. 239, 339-342 (1988)

16 Giraldo, E., Alessandra, V.M. and Ladinsky, H.: Characterization of muscarinic receptor in guinea pig ileum longitudinal smooth muscle. Mol. Pharmacol. 33, 617-625 (1988)

17 Dorje, F., Levey, A.I. and Brainn, M.R.: Immunological detection of muscarinic receptor subtype proteins $\left(\mathrm{m}_{1}-\mathrm{m}_{5}\right)$ in rabbit peripheral tissues. Mol. Pharmacol. 40, 459-462 (1991)

18 Konno, F. and Takayanagi, I.: Relationship between the contractile responses and coupling second messenger systems for muscarinic drugs in the guinea pig ileal longitudinal muscle. Arch. Int. Pharmacodyn. Ther. 301, 15-29 (1989)

19 Lambrecht, G., Feifel, R., Moser, U., Warger, M., Choo, L.K., Camus, J., Tastenoy, M., Waelbroek, M., Strohmann, C., Tacke, R., Rodrigues, J.F., Christophe, J. and Mutshler, E.: Pharmacology of hexahydro-difenidol, hexahydro-siladifenidol and related selective muscarinic antagonists. Trends Pharmacol. Sci. 10, Supp. $61-64$ (1989)

20 Takano, Y., Uchimura, K., Kohjimoto, Y. and Kamiya, H.: Properties and distribution of muscarinic cholinergic receptors in rat striatal micropunched tissue homogenates. Eur. J. Pharmacol. 70, 559-564 (1981)

21 Honda, K., Takano, Y., Yamada, A. and Kamiya, H.: Relationship between substance $\mathrm{P}$-induced initial transient contractions and inositol phospholipid hydrolysis in guinea pig ileum. J.
Pharmacobiodyn. 14, 393-397 (1991)

22 Berridge, M.J., Dawson, C.P., Downes, C.P., Heslop, J.P. and Irvine, R.F.: Change in the levels of inositol phosphates after agonist-dependent hydrolysis of membrane phosphoinositides. Biochem. J. 212, 473-482 (1983)

23 Lowry, O., Rosebrough, N. J., Farr, L. and Randall, R.J.: Protein measurement with the Folin phenol reagent. J. Biol. Chem. 193, 265-275 (1951)

24 Fisher, S.T. and Bartus, R.T.: Regional differences in the coupling of muscarinic receptors to inositol phospholipids hydrolysis in guinea pig brain. J. Neurochem. 45, 1085-1095 (1985)

25 Noronha-Blob, L., Canning, B., Costello, D. and Kinnier, W.J.: Selective agents for muscarinic receptors linked to phosphoinositide breakdown. Eur. J. Pharmacol. 154, 161-167 (1988)

26 Masters, S.B., Harden, T.K. and Brown, J.H.: Relationships between phosphoinositide and calcium responses to muscarinic agonists in astrocytoma cells. Mol. Pharmacol. 26, 149-155 (1984)

27 Brown, J.H., Goldstein, D. and Masters, S.B.: The putative $M_{1}$ muscarinic receptor does not regulate phosphoinositide hydrolysis: studies with pirenzepine and McN-A-343 in chick heart and astocytoma cells. Mol. Pharmacol. 27, 525-531 (1985)

28 Noronha-Blob, L., Lowe, V.C., Hanson, R. and U'Prichard, D.C.: Heterogeneity of muscarinic receptors coupled to phosphoinositide breakdown in guinea pig brain and peripheral tissues. Life Sci. 41, 967-975 (1987)

29 Graldordy, B.M., Cuss, F.M., Sampson, A.S., Palmer, J.B. and Branes, P.L.: Phosphatidylinositol response to cholinergic agonists in airway smooth muscle: relationship to contraction and muscarinic receptor occupancy. J. Pharmacol. Exp. Ther. 238, 273-279 (1986)

30 Akhtar, R.A., Honkanen, R.E., Howe, P.H. and Abdel-Latif, A.A.: $M_{2}$ muscarinic receptor subtype is associated with inositol trisphosphate accumulation, myosin light chain phosphorylation and contraction in sphincter smooth muscle of rabbit iris. J. Pharmacol. Exp. Ther. 243, 624-632 (1987)

31 Egalen, R.M., Michel, A.B. and Whiting, R.L.: Characterization of the muscarinic receptor subtype mediating contraction of the guinea pig uterus. Br. J. Pharmacol. 96, 497-499 (1989)

32 Nilvebrant, L. and Bengt, S.: Receptor binding profiles of some selective muscarinic antagonists. Eur. J. Pharmacol. 151, $83-96$ (1988)

33 Mei, L., Roeske, W.R. and Yamamura, H.I.: Molecular pharmacology of muscarinic receptor heterogeneity. Life Sci. 45, 1831 - 1851 (1989)

34 Michel, A.D. and Whiting, R.L.: Methoctramine reveals heterogeneity of $\mathbf{M}_{2}$ muscarinic receptors in longitudinal ileal smooth muscle membranes. Eur. J. Pharmacol. 145, 305-311 (1988)

35 Michel, A.D. and Whiting, R.L.: The binding of $\left[{ }^{3} \mathrm{H}\right] 4$ diphenylacetoxy- $N$-methylpiperidine methiodide to longitudinal ileal smooth muscle muscarinic receptors. Eur. J. Pharmacol. 176, 197-205 (1990) 